\title{
Susceptibilities to Carbapenems and Presence of cphA Gene on Food-Borne Aeromonas
}

\author{
Bibiana María Martín Talavera ${ }^{1}$, Fernando Olivio Benassi ${ }^{1}$, Martha Helena von Specht ${ }^{1 *}$, \\ Marina Inés Quiroga ${ }^{1}$, Myriam Alicia García ${ }^{1}$, Amanda Beatríz Pucciarelli ${ }^{1}$, Emilce \\ Zubreski $^{1}$, Margarita Esther Laczeski ${ }^{1}$ and Gabriel Gutkind ${ }^{2}$ \\ ${ }^{1}$ Centro de Investigación y Desarrollo Tecnológico - Bidet; Facultad de Ciencias Exactas, Químicas y Naturales; \\ Universidad Nacional de Misiones; Félix de Azara, 1552; 3300 Posadas; Misiones - Argentina. ${ }^{2}$ Cátedra de \\ Microbiología; Facultad de Farmacia y Bioquímica; Universidad de Buenos Aires; Buenos Aires - Argentina
}

\begin{abstract}
The purpose of this study was to determine the susceptibilities of food-borne Aeromonas to carbapenems, as well as to investigate the presence of a metallo carbapenemase-encoding gene, named cphA. Minimum Inhibitory Concentration (MIC) was determined following NCCLS standards. All the tested microorganisms were susceptible to imipenem, meropenem and biapenem. However, a strong inoculum size effect on carbapenem MICs was observed for most of the strains. Six strains, out of seven, showed the presence of metallo-- $\beta$-lactamases but cphA gene was detected in only two strains of A. veronii $b v$. sobria.
\end{abstract}

Key words: metallocarbapenemase, cphA gene, food borne Aeromonas.

\section{INTRODUCTION}

Evolution of bacterial resistance to antibiotics in humans, animals and the environment is the result of the interaction between the exposure to antibiotics, selection of microorganisms carrying primordial genes of resistance, and transmission of resistance genes between bacteria. Selective effects occur in selective compartments, where particular antibiotic concentrations result in a differential growth rate of resistant bacterial variants (Baquero et al., 1998) This may happen even at very low antibiotic concentrations able to select low-level-resistant bacteria. Analysis of selective environment-related antibiotic-hostbacteria interactions is essential to understand the biology of antibiotic resistance. (Baquero et al., 1998)
To anticipate emergence of resistance, it is necessary to better understand the genetics and biochemistry of resistance mechanisms and to develop methodologies to foresee their evolution at the individual or population level (Baquero et al., 1998). Most retrospective and prospective studies show that after the introduction of an antibiotic, the level of resistance increases both among pathogenic bacteria and in commensal bacteria (van den Bogaard and Stobberingh, 2000). Moreover, commensal bacteria constitute a reservoir of resistance genes for (potentially) pathogenic bacteria. Their level of resistance is considered to be a good indicator for selection pressure by antibiotic use and for resistance problems to be expected in pathogens.

Aeromonas strains have been found to be able to produce up to three different $\beta$-lactamases

\footnotetext{
${ }^{*}$ Author for correspondence
} 
including a group 1 (according to the BushJacoby-Medeiros classification) molecular class C cephalosporinase, a group $2 \mathrm{~d}$ molecular class D penicillinase and a group 3 molecular class B metallo $\beta$-lactamases (Hayes et al., 1994; Walsh et al., 1995). Among the different types of $\beta$ lactamases found in aeromonads, the molecular class B enzymes are particularly interesting from the clinical standpoint because of their ability to hydrolyze carbapenem compounds (which are broad-spectrum antibiotics not hydrolyzed by most other $\beta$-lactamases) and contribute to resistance against these antimicrobial agents (Massida et al., 1991; Morita et al., 1994; Rossolini et al., 1995; Sanders et al., 1989). Metallo- $\beta$-lactamases (class $B$ of the molecular classification of Ambler or group 3 according to the functional classification of Buch et all) constitute a very heterogeneus family. (Mercuri et al., 2001).

On the basis of structural analysis, these enzymes cluster into three different groups: subclass B1 contains most known zink- $\beta$-lactamases for example BcII from Bacillus cereus $569 \mathrm{H}$ (Hussain et al., 1985) and the plasmid-encoded enzyme IMP-1 found in some isolates of Pseudomonas aeruginos, Serratia marcescens and other Gram negative bacteria (Laraki et al., 1999; Osano et al., 1994), subclass B2 includess the Aeromonas enzymes (CphA, ImiS, and CphA2; Mercuri et al., 2001) and subclass B3 contains for example the tetrameric L1 enzyme produced by Stenotrophomonas maltophilia (Sanchagrin et al., 1998).

The enzymes from Aeromonas species are known as "true carbapenemases". These enzymes have a high specificity for hydrolyzing carbapenems and cannot be detected with nitrocefin. (Rossolini et al., 1996) In a survey performed on reference Aeromonas strains of several different species, it was observed that production of carbapenemase activity was restricted to strains of some species, being not detectable in others and that in all cases this activity was inhibited by EDTA (Rossolini et al., 1995) An A. hydrophila metallo carbapenemase-encoding gene, named $c p h A$, has been cloned from a clinical isolate (Massida et al., 1991) Experiments showed that cphA-specific probes recognize A. hydrophila, A. veronii bv. sobria, $A$. veronii bv veronii, $A$ jandaei, $A$. salmonicida (both subsp. salmonicida and subsp. achromogenes) but not A. caviae (with a few exceptions), A. trota, or A. schubertii strains (Rossolini et al., 1995; Rossolini et al., 1996)

Similar to other chromosomally encoded $\beta$-lactamases types, the production of the class B enzyme is normally regulated in Aeromonas strains: the enzyme is produced at negligible levels in the absence of suitable inducers, while production increases several hundredfold in the presence of a suitable $\beta$-lactam inducer such as penicillin or imipenem (Hayes et al., 1994; Massida et al., 1991; Segatore et al., 1993; Walsh et al., 1995). Aeromonas spp. are indigenous to acquatic environments (Warren et al. 2004), and have become increasingly implicated as causative agents of food borne associated human diseases such as gastroenteritis (Abeyta et al., 1986; Kirov et al., 1990). Accute diarrheal outbreaks in longterm care settings were reported (Bloom et al., 1990).

The aim of this work was to study the susceptibility patterns of carbapenems on Aeromonas strains, isolated from chicken carcasses, and to detect cphA gene presence on Aeromonas sp. producing a carbapenemase activity.

\section{MATERIALS AND METHODS}

\section{Bacterial strains}

Seven Aeromonas strains isolated from chicken carcasses were used in this study. These were $A$ veronii biov. sobria (3) and A caviae (4) (Benassi et al., 2001).

\section{In vitro susceptibility tests}

MIC's of selected antibiotics were tested by agar dilution method (National Committee for Clinical Laboratory Standards: 1999; NCCLS 2003) with Mueller Hinton Agar (Bickar, France), with inocula of $10^{5}$ (normal) and $10^{7-8}$ (high) CFU/per spot on the plate using a Steers replicator. MIC's were determined the following compounds: Imipenem (IMP- Merck Sharp \& Dohme Research Laboratories - Rahway, N. Y., USA), Meropenem (MER - Zeneca Pharma - Italy), Biapenem (BIACyenamid -Italy). These were obtained as powders with known potency.

\section{$\beta$-lactamase production}

Microorganisms were grown overnight in $50 \mathrm{ml}$ of Brain Heart Infusion (BHI- Britania, Argentina), 
contained in $250 \mathrm{ml}$ flasks at $37^{\circ} \mathrm{C}$ and $200 \mathrm{rpm}$. Cultures were collected 2-h after induction with $100 \mu \mathrm{g} / \mathrm{ml}$ anhydrous ampicillin, centrifuged at $10,000 \mathrm{x} \mathrm{g}$ and resuspended in $5 \mathrm{ml}$ of $30 \mathrm{mM}$ sodium phosphate buffer ( $\mathrm{pH}$ 7.2). The cells were disrupted by vortexing with sand $(\mathrm{HCl}$ washed) (particles $0.10-0.15 \mathrm{~mm}, 1: 1$, w/v sand to cells ratio, $10 \times 1 \mathrm{~min}$ each, $0{ }^{\circ} \mathrm{C}$ ). Crude cells extracts were centrifuged $(15,000 \mathrm{x} \mathrm{g})$ to remove bacterial debris and were stored at $-20{ }^{\circ} \mathrm{C}$ until used.

\section{Determination of $\beta$-lactamase activity}

Detection of $\beta$-lactamase was performed by an iodometric technique with $1000 \mu \mathrm{g} / \mathrm{ml} \mathrm{IMP}$ as the substrate (Quinteros et al., 1990).

\section{Inhibition experiments}

The susceptibility of $\beta$-lactamases to inhibition by EDTA $(10 \mathrm{mM}$ final concentration) was determined by the iodometric method after incubation of the crude extracts $(20 \mu \mathrm{l})$ for twenty minutes at $25^{\circ} \mathrm{C}$ in the presence of $10 \mu \mathrm{M}$ EDTA. IMP $(1000 \mu \mathrm{g} / \mathrm{ml})$ was used as the substrate. In all cases, a control assay without EDTA was run in parallel.

\section{PCR Analysis}

The PCR analysis to detect the presence of cphA gene was performed as described by Massida et al. Cromosomal DNA was extracted from the carbapenemase producers strains. The set of primers used was ANY-SSD/F (5' GCT TAG AGC TCC TAA GGA GCA AGA TGA AAG GTT GG 3' and 5' GCA TAG GTA CCT TAT GAC TGG GGT GCG GCC TTG 3') (Massida et al.,1991).

\section{RESULTS}

Table 1 shows MIC for IMP, MER and BIA of the strains studied. All the strains were susceptible to IMP: $\mathrm{CIM}_{90}=0.5 \mu \mathrm{g} / \mathrm{ml}$, MER: $\mathrm{CIM}_{90}=0.125$ $\mu \mathrm{g} / \mathrm{ml}$, and BIA: $\mathrm{CIM}_{90}=0.125 \mu \mathrm{g} / \mathrm{ml}$. When a large inoculum size was used, an impact was observed: $85.7 \%$ for imipenem, $71.5 \%$ for meropenem and $100 \%$ for biapenem. (Table 1). Table 2 shows the results of the metallo $\beta$ lactamase experimentsand the presence of the cphA gene.Figure 1 presents the results of PCR amplification with primers ANY-SSD/F of the cphA gene.

Table 1 - Minimal inhibitory concentration and inoculum size effect

\begin{tabular}{|c|c|c|c|c|c|c|c|c|c|c|}
\hline \multirow[t]{2}{*}{ SPECIES } & \multirow[t]{2}{*}{$\mathrm{N}^{\circ}$ strain. } & \multicolumn{3}{|c|}{ Imipenem } & \multicolumn{3}{|c|}{ Meropenem } & \multicolumn{3}{|c|}{ Biapenem } \\
\hline & & $\begin{array}{c}\text { N.I * } \\
(\mu \mathrm{g} / \mathrm{ml})\end{array}$ & $\begin{array}{c}\text { H.I* } \\
(\mu \mathrm{g} / \mathrm{ml})\end{array}$ & I.E.* & $\begin{array}{c}\text { N.I. } \\
(\mu \mathrm{g} / \mathrm{ml})\end{array}$ & $\begin{array}{c}\text { H.I. } \\
(\mu \mathrm{g} / \mathrm{ml})\end{array}$ & I.E. & $\begin{array}{c}\text { N.I. } \\
(\mu \mathrm{g} / \mathrm{ml})\end{array}$ & $\begin{array}{c}\text { H.I. } \\
(\mu \mathrm{g} / \mathrm{ml})\end{array}$ & I.E \\
\hline A. caviae & 66 & 0.25 & 1 & No & 0.06 & 0.25 & No & $<0.03$ & 0.5 & Yes \\
\hline A. caviae & 73 & 0.06 & 0.5 & Yes & 0.06 & 0.125 & No & 0.06 & 2 & Yes \\
\hline A. caviae & 78 & 0.06 & 1 & Yes & $<0.03$ & 4 & Yes & 0.06 & 4 & Yes \\
\hline A. caviae & 74 & 0.5 & $>8$ & Yes & $<0.03$ & $>8$ & Yes & 0.06 & 8 & Yes \\
\hline A. ver. sobria & 79 & 0.5 & $>8$ & Yes & $<0.03$ & $>8$ & Yes & 0.06 & $>8$ & Yes \\
\hline A. ver. sobria & 64 & 0.5 & $>8$ & Yes & 0.25 & $>8$ & Yes & 0.06 & 8 & Yes \\
\hline A. ver. sobria & 82 & 0.5 & 8 & Yes & $<0.03$ & $>8$ & Yes & $<0.03$ & $>8$ & Yes \\
\hline
\end{tabular}

* (NI): normal inoculum, $10^{5}$ CFU/per spot; (HI): high inoculum, $10^{7-8}$ CFU/per spot; (IE): inoculum effect.

Table 2 - Metallo- $\beta$-lactamase production and $c p h A$ gene detection

\begin{tabular}{lccc}
\hline Species (strain $\mathbf{N}^{\mathbf{0}}$ ) & $\begin{array}{c}\text { Iodometric Technique } \\
\text { with Imipenem. }\end{array}$ & $\begin{array}{c}\text { Inactivation Experiments } \\
\text { with EDTA }\end{array}$ & cph A gene \\
\hline A.caviae (66) & + & + & - \\
A.caviae (73) & + & + & - \\
A.caviae (78) & + & + & - \\
A.caviae (74) & + & + & - \\
A.ver.sobria (79) & + & - & + \\
A.ver.sobria (64) & + & + & + \\
A.ver.sobria (82) & + & + & + \\
\hline
\end{tabular}

* (+): positive detection; (-): negative detection. 


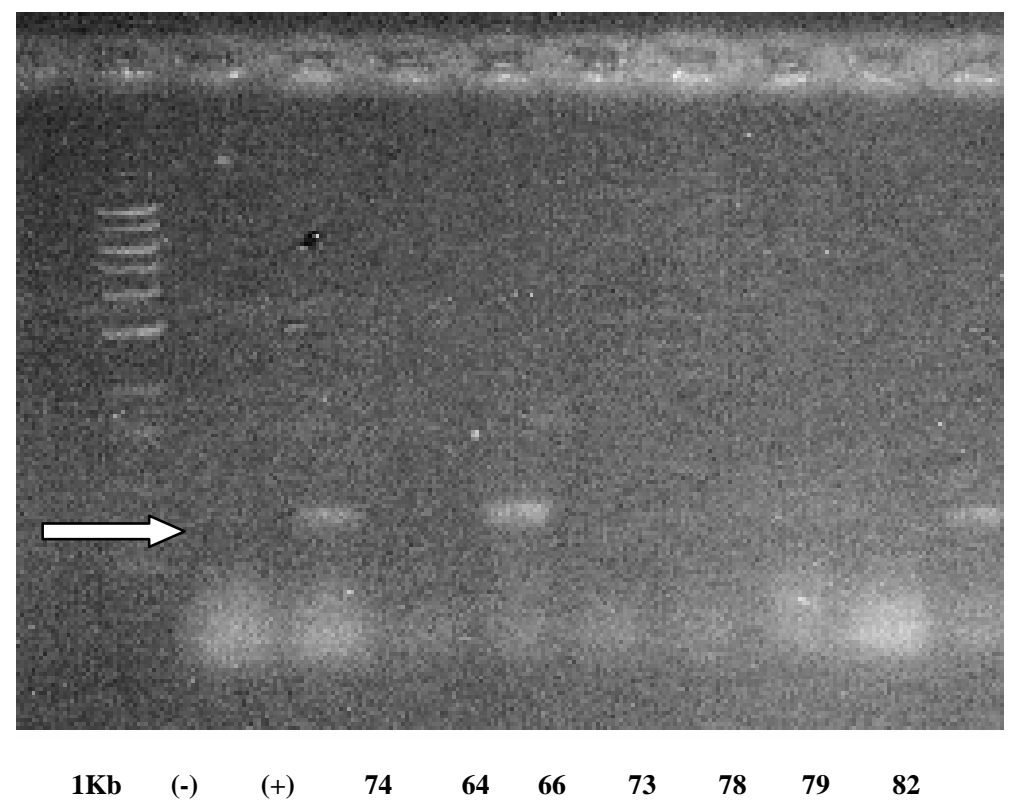

Figure 1 - PCR amplification with primers ANY-SSD/F of the $c p h A$ gene $1 \mathrm{~Kb}$ : Ladder; 74: $A$. caviae; 64: A. veronii bv.sobria; 66: A. caviae; 73: A. caviae; 78: A. caviae; 79: A. veronii bv.sobria; 82: A. veronii bv.sobria. (+) Positive control, (-) Negative control.

\section{DISCUSSION}

It has been reported that metallo- $\beta$-lactamase mediated resistance phenotype could not readily recognized in conventional in vitro susceptibility testing (Bakken et al., 1988; Hayes et al., 1994; Massida et al., 1991; Rossolini et al 1995). This appeared to be the case for carbapenems antibiotics and carbapenemase-producing strains in the present study also. Results showed a strong inoculum size effect on carbapenem MICs, with few A. caviae as exceptions. This effect was also observed Rossolini et al. (1996) who related it with carbapenemase producing Aeromonas strains. In fact, using larger inocula $\left(10^{8} \mathrm{CFU} / \mathrm{ml}\right)$, carbapenems MICs for these strains become usually higher than the breakpoint for susceptibility, while carbapenems MICs of Aeromonas strains that do not express a carbapenemase activity (such as the majority of $A$. caviae strains) remain always below the breakpoint for susceptibility. This seems to be the situation largely found in most of contaminated foods related with foodborne diseases.

EDTA inhibition of carbapenems activity suggested their metallo enzimes nature.Rossolini et al (1995) found that production of metallo carbapenemase activity was restricted to strains of some species, being not detectable in others, and that in all the cases this activity was inhibited by EDTA. However, a minority of $A$. veronii bv. sobria strains was found to be unable to produce the enzyme, while a minority of A. caviae strains expressed similar activity.

Although most of the phenotypes expressed by the strains studied were of carbapenemase activity, cphA gene aleles was detected in two strains of $A$. veronii bv sobria. However, it appeared more likely to consider that other carbapenemases (still to be characterized), might be present in strain 79, different enough to $c p h A$ gene as not to react with the specific primers. The lack of its presence in $A$. caviae was in accordance with other research findings (Rossolini et al. 1995, 1996). Furthermore, it would be always advisable to perform susceptibility testing, also with large inocula, or looking for carbapenemase production. The possibility of horizontal transfer of cphA alleles to strains of species that normally do not carry it, must be considered. Most known metallo$\beta$-lactamases are encoded by chromosomal genes of some bacterial species that are primarily members of the environmental microbiota, such as Aeromonas spp., whereas some as yet unknown environmental species are the most likely sources of the mobile metallo- $\beta$-lactamases determinants 
that recently appeared among gramnegative patogens. (Rosolini et al., 2001)

The emergence of resistant bacteria and resistance genes following the use of antimicrobial agents is relatively well documented and it seems evident that all antimicrobial agents would select for resistance (Aarestrup 1999). The occurrence of a transmitted food disease due to metallo$\beta$-lactamases producers microorganisms would limit the efficiency of a carbapenem-based chemotherapy in the treatment of human infections.

\section{RESUMO}

O objetivo deste estudo foi determinar a suscetibilidade de aeromonas de origem alimentar a carbapenems bem como investigar a presença de um gene codificante de metalocarbapenemase, denominado "cph A". A suscetibilidade in vitro foi determinada pelo metodo de diluição em agar. Todas as cepas foram suscetíveis a Imipenem, Meropenem e Biapenem. Porém foi observado um forte efeito de tamanho do inóculo sobre as CIM das carbapenems na maioria das cepas. A detecção de metalo- $\beta$-lactamase foi realizada pelo metodo lodometrico. Seis cepas das sete testadas demostraron a presença da enzima. A presença do gene $c p h A$ foi determinada por PCR $\mathrm{e}$ foi detectada em duas cepas de A veronii bv. sobria.

\section{REFERENCES}

Aarestrup, F. M. (1999), Association between the consumption of antimicrobial agents in animal husbandry and the occurrence of resistant bacteria among food. Int. J. Antimicrob. Agents., 4, 279-85.

Abeyta, C. J.; Kaysner, C. A.; Wekell, M. M.; Sullivan, J. J. and Stelma, G. N. (1986), Recovery of Aeromonas hydrophila from oysters implicated in an outbreak of food borne illness. J. Food Protection., 49, 643-646.

Bakken, J. S.; Sanders, C. C.; Clark, R. B. and Hori, M. (1988), $\beta$-lactam resistance in Aeromonas spp caused by inducible $\beta$ - lactamases active against penicillins, cephalosporins, and carbapenems. Antimicrob. Agents Chemother., 32, 1314 - 1319.

Baquero, F.; Negri, M. C.; Morosini, M. I. and Blazquez, J. (1998), Antibiotic- Selective Environments. Clin. Infect. Dis., 27 : (Supl. 1), S5-11.
Benassi, F. O.; Vergara, M.; von Specht, M. H.; García M. A.; Quiroga, M. I.; Pucciarelli, A. B.; Zubreski, E.; Laczeski, M.; Martín, B. M.; Leardini, N. and Gutkind, G. (2001), Estudio de susceptibilidad a antibióticos $\beta$-lactamicos en Aeromonas spp. de origen clínico, animal y ambiental. Rev. Arg. Microbiol., 33, 47-51

Bloom, H. and Bottone, E. (1190), Aeromonas hydrophila diarrhea in a long-term care setting. $J$. Am. Geriatr. Soc., 38 : (7), 804-806.

Hayes, M. V.; Thomson, C. J. and Amyes, S. G. B. (1994), Three $\beta$-lactamases isolated from Aeromonas salmonicida, including a carbapenemase not detectable by conventional methods. Eur. J. Clin. Microbiol. Infect. Dis., 13, 805-811

Hussain, M.; Carlino, A.; Maddona, M. and Lampen, O. (1985), Cloning and sequencing of the metallothioprotein $\beta$-lactamase II gene of Bacillus cereus $569 \mathrm{H}$ in Escherichia coli. J. Bacteriol., 164, 223-229.

Laraki, N.; Galleni, M.; Thamm, I.; Riccio, M.; Amicosante, G. and Rossolini, G. (1999), Structure of In31, a blaIMP-containing Pseudomonas aeruginosa integron phyletically related to In5, which carries an unusual array of gene cassettes. Antimicrob. Agents Chemother., 43, 890-901.

Kirov, S. M.; Anderson, M. J. and Mc Meekin, T. A. (1990), A note on Aeromonas spp. from chickens as possible food borne pathogens. J. Appl. Bacteriol., 68, 327-334

Massida, O.; Rossolini, G. M. and Satta, G. (1991), The Aeromonas hydrophila cphA gene: Molecular heterogeneity among class B metallo $\beta$-lactamases. J. Bacteriol., 173, 4611-4617.

Mercuri, P.; Bouillene, F.; Boschi, L.; LammotteBrasseur, J.; Amicosante, G.; Devreese, B.; Van Beeumen, J.; Frère, J.; Rossolini, G. and Galleni, M. (2001), Biochemical Characterization of the FEZ-1 metallo $\beta$-lactamase of Legionella gormanii ATCC 33297T Produced in Escherichia coli. Antimicrob. Agents Chemother., 45, 1254-1262.

Morita, K.; Watanabe, N.; Kurata, S. and Kanamori, M. (1994), $\beta$-lactam resistance of motile Aeromonas isolates from clinical and environmental sources. Antimicrob. Agents Chemother., 39, 346-349.

National Committee for Clinical Laboratory Standards. (1999), Performance standards for antimicrobial disk susceptibility tests. Ninth informational supplement. NCCLS document M100-S9. National Committee for Clinical Laboratory Standards, Wayne, Pa.

National Committee for Clinical Laboratory Standards (2003), Methods for dilution antimicrobial susceptibility for bacterial that grow aerobically. ed. Approved Standard - $6^{\text {th }}$ ed. NCCLS document M7A6. Wayne, PA: NCCLS. 
Osano, E.; Arakawa, Y.; Wacharotayankun, R.; Ohta, M.; Horii, T.; Ito, H.; Yoshimura, F. and Kato, N. (1994), Molecuar characterization of an eterobacterial $\beta$-lactamase found in a clinical isolate of Serratia marcescens that shows imipenem resistance. Antimicrob. Agents Chemother., 38, 71-78.

Quinteros, M., Corso, A., Galas, M., Gutkind, G. and Rossi, A. (1990), Clave orientadora para la detección de $\beta$-lactamasas. Libro de resúmenes II Congreso Internacional de SADEBAC, C10. Argentina.

Rossolini, G. M.; Zanchi, A.; Chiesurin, A.; Amicosante G.; Satta, G. and Guglielmetti, P. (1995), Distribution of cphA or related carbapenemaseencoding genes and production of carbapenemase activity in members of the genus Aeromonas. Antimicrob. Agents Chemother., 39, 346-349.

Rossolini, G. M.; Walsh, T. and Amicosante, G. (1996), The Aeromonas Metallo- $\beta$-lactamases: Genetics, Enzimology, and contribution to Drug Resistance. Microbial Drug Resistance., 2 : (2), 245-252.

Rossolini, G.; Condemi, M.; Pantenella, F.; Docquier, J.; Amicosante, G. and Thaller, M. C. (2001), Metallo- $\beta$-lactamase producers in environmental microbiota: new molecular class B enzyme in Janthinobacterium lividum. Antimicrob. Agents Chemother., 45 : (3), 837-844.

Sanchagrin, F.; Dufrense, J. and Levesque, R. (1998), Molecular heterogeneity of the L-1 metalo- $\beta$ lactamase family from Stenotrophomonas maltophilia. Antimicrob. Agents Chemother., 42, 1245-1248.

Sanders, C. C.; Sanders Jr., W. E.; Thomson, K. S. and Iaconis, J. P. (1989), Meropenem Activity against resistant gram-negative bacteria and interactions with $\beta$-lactamases. J. Antimicrob. Agents Chemother., 17, 45-50.
Segatore, B.; Massida, O.; Satta, G.; Setacci, D. and Amicosante, G. (1993), High specificity of cphAencoded metallo- $\beta$-lactamase from Aeromonas hydrophila AE036 for carbapenems and its contribution to $\beta$-lactam resistance. Antimicrob. Agents Chemother., 37, 1324-1328.

Van Den Bogaard, A. E. and Stobberingh, E. E. (2000), Epidemiology of resistance to antibiotics links between animals and humans International $J$. Antimicrob. Agents., 14, 327-335.

Walsh, T. R.; Payne, D. J.; McGowan, A. P. and Bennett, P. M. (1995), A clinical isolate of Aeromonas sobria with three chromosomally mediated inducible $\beta$-lactamases: A cephalosporinase, a penicillinase, and a third enzyme displaying carbapenemase activity. J. Antimicrob. Chemother., 35, 271-279.

Warren, W. J.; Jeter, R.; Kimbrough, R. M. and Zak, J.C. (2004), Population patterns and antimicrobial resistance of Aeromonas in urban playa lakes. Can. J. Microbiol., 50 : (6), 397-404.

Received: September 23, 2004; Revised: March 02, 2005; Accepted: March 14, 2006. 